\title{
Aile Sağlı̆̆ı Merkezine Başvuran Gebelerde Obezite Sıklığının ve Obezitenin Yaşam Kalitesine Etkisinin İncelenmesi
}

\section{Investigation of theEffect Of Obesity and Obesity on Life Quality in Pregnancy Following Family Health Center}

\author{
Rukiye DOĞAN ${ }^{\mathrm{a}}$, Fatma Deniz SAYINER ${ }^{\mathrm{b}}$, Hüseyin Mete TANIR ${ }^{\mathrm{c}}$
}

\begin{abstract}
ÖZ Amaç: Obezite, Dünya Sağlık Örgütü tarafindan "Sağlığı bozacak ölçüde vücutta anormal veya aşırı yağ birikmesi" olarak tanımlanmaktadır. Obezite günlük yaşam aktivitelerini azaltan, sosyal ve psikolojik etkileri nedeniyle yaşam kalitesini doğrudan etkileyen bir sağlık problemidir ve obez kadınlarda gebelikte obezite ile ilgili yaşam kalitesinde önemli derecede bozulmalar görülmektedir. Bu çalışma, gebelikte obezite prevalansını ve yaşam kalitesine etkisini değerlendirmek amacıyla planlanmıştır. Gereç ve Yöntem: Çalışma Aile Sağlı̆̆ı Merkezi'ne bir yılda başvuran 400 gebe kadın üzerinde yapılmışıı. Veri toplama aracı olarak "Gebelerde Obezite Değerlendirme Anket" formu ve "SF- 36 Yaşam Kalitesi Ölçeği" kullanıldı. İstatistiksel değerlendirmede ki kare testi ve student $\mathrm{t}$ testi kullanıldı. Bulgular: Gebelik öncesi obezite sıklığı \%18.8 olarak bulundu. Obezite görülme durumu ile yaş, aile gelir durumu, ailede obezite öyküsü, günlük uyku ve televizyon izleme süresi, canlı doğum sayısı, iri bebek öyküsü, son doğum şekli, öğün atlama, hızlı yemek yeme, gece yemek yeme, ayaküstü beslenme alışkanlığı arasında istatistiksel olarak anlamlı fark bulundu $(\mathrm{p}<0.05)$. Kronik hastalık varlığ 1 , düzenli fiziksel aktivite, evlilik süresi ve infertilite tedavisi ile obezite arasında istatistiksel anlamlı ilişki bulundu $(\mathrm{p}<0.001)$. Sonuç: Gebelik öncesi VKİ $\geq 30 \mathrm{~kg} / \mathrm{m}^{2}$ üzeri olan kadınların gebelikte yaşam kalitelerinin daha düşük olduğu tespit edildi. $\mathrm{Bu}$ bağlamda obez gebelerde doğum öncesi bakım normal kilolu gebelerden daha önemlidir. Gebelik düşünen obez kadınlar için kilo vermeye yönelik beslenme ve egzersiz programlarının gebelik öncesi dönemde planlanması gerekmektedir.
\end{abstract}

Anahtar sözcükler: Gebelik, obezite, yaşam kalitesi.

ABSTRACT Aim: Obesity is defined by the World Health Organization as "normal or excessive fat accumulation in the body enough to affect health negatively". Increasing prevelance of obesity is a serious problem for health service of the pregnant women. Obesity is an important problem for the pregnant women and is considered as the most important problem and is of top priority in terms of the complications it causes. Obesity is a health problem reducing daily life activities and affecting directly the life quality due to its social and psychological effects, and significant deteriotation could be seen regarding obesity in pregnancy. This study was conducted to evaluate the quality of life and the prevalence of obesity in pregnancy. Methods: This study was conducted on 400 pregnant women who applied to the Family Health Center in a year. Data collection tool "Obesity in Pregnancy Assessment Questionnaire" form and the "SF-36 Quality of Life Scale" was used. Chi-square test and student t-test were used in statistical evaluation. Results: Prepregnancy obesity prevelance was found $18.8 \%$. Obesity was observed statistically between age and family income status, family history of obesity, daily sleep and watching television, number of live births, history of macrosomic baby, last birth type, skip repast, eating fas, eating at night and eating fast food habits found significant difference $(p<0.05)$. There was a statistically significant correlation between presence of chronic disease, regular physical activity, marriage duration and infertility treatment and obesity $(\mathrm{p}<0.001)$. Conclusion: It was determined that pre-pregnancy women with BMI $\geq 30 \mathrm{~kg} /$ $\mathrm{m}^{2}$ had lower quality of life in gestation. In this context, prenatal care in obese pregnancies is more important than normal weight pregnancies. For obese women who are considering pregnancy, weight loss diet and exercise programs should be planned before pregnancy.

Key words: Pregnancy, obesity, life quality

\section{Giriş}

Obezite, Dünya Sağlık Örgütü (DSÖ) tarafindan "Sağlığı bozacak ölçüde vücutta anormal veya aşırı yağ birikmesi“" olarak tanımlanmaktadır. ${ }^{1}$ Fiziksel ve ruhsal sorunlara neden olan obezite

iş gücünü azaltması, ülke ekonomisini etkilemesi ve kişiyi toplumdan soyutlaması nedeniyle sosyal bir sorundur. ${ }^{2}$ Son y1llarda obezite sıklığındaki artış ile birlikte obezitenin

\footnotetext{
Geliş Tarihi/Received: 04-08-2017/ Kabul Tarihi/Accepted:01-12-2018

a Eskişehir Osmangazi Üniversitesi Tıp Fakültesi,e-mail: rukiyedogan_@ hotmail.com, ORCID: 0000-0002-8641-425x

${ }^{\text {b} D o c ̧ . ~ D r ., ~ E s k i s ̧ e h i r ~ O s m a n g a z i ~ U ̈ n i v e r s i t e s i ~ S a g ̆ l ı k ~ B i l i m l e r i ~ F a k u ̈ l t e s i ~ E b e l i k ~ B o ̈ l u ̈ m u ̈, ~}$ email:denizsayiner@gmail.com, ORCID:0000-0001-9287-989X

c Prof. Dr. Eskişehir Osmangazi Üniversitesi Tıp Fakültesi,e-mail: mtanir@ superonline.com, ORCID: 0000-0003-2980-630X

Sorumlu yazar /Correspondence: Doç. Dr. Fatma Deniz Sayıner, Eskişehir Osmangazi Üniversitesi Sağlık

Bilimleri Fakültesi Ebelik Bölümü, e-mail:denizsayiner@gmail.com
} 
sağlık durumuna etkilerinin kanitlarla ortaya konması sağlik hizmetlerinin sunumunda ve planlanmasında değişiklikler yaratmıştır. Obezite, kısa ve uzun dönem önemli sağl1k riskleri ile obstetrik durumlarda yüksek risk teşkil etmesi nedeniyle çözülmesi gereken öncelikli sorun haline gelmiştir.

Gebelerin sağlik durumlarının incelendiği birçok çalışmada obezite sıklığındaki artış dikkat çekici düzeydedir. 2002-2004 yılları arasında İskoçya'da yapılan bir çalışmada doğum öncesi bakım için başvuran her beş kadından birinin obez olduğu rapor edilmiştir ve bu oranın 10 yıl öncesine göre iki kat daha fazla olduğu bildirilmiştir. ${ }^{3,4}$ Türkiye Nüfus ve Sağlik Araştırmas1 (TNSA) 2013 raporuna göre, Türkiye' de 15-49 yaş aralığındaki kadınların $\% 27$ 'sinin obez olduğu bildirilmiştir. ${ }^{38}$ Annenin fazla kilolu veya obez olmasi maternal ve fetal morbidite ve mortalite, gebelik komplikasyonları ve artan doğum defekti bakımından ciddi riskler oluşturmaktadır. Özellikle obez kadınların olmayanlara göre sezaryen olma oranı iki kat artmaktadır (Tablo 1). ${ }^{5,6}$ Maternal obezite geç dönemde çocuk için obezitenin artmış bir riski olduğu kadar, çocuk ve anne için tip 2 diyabetin de artmış bir riskidir. ${ }^{7-10} \mathrm{Bu}$ çalışma, gebelikte obezite prevalansını ve yaşam kalitesine etkisini değerlendirmek amacıyla yapılmıştır. katılmaya gönüllü olan gebeler oluşturmuştur. Örneklem seçimine gidilmemiş olup tüm evrene ulaşılmaya çalışıldı. Araştırma verilerinin toplandığ tarihler arasında Aile Sağlığı Merkezi'nde izlenen 511 (evren) gebe olduğu bildirildi. Ancak, araştırmacı verilen adreslere gittiğinde bu gebelerden 28 'i doğum yaptığ 1 , 20 'sinin ise gebeliği düşük ile sonlandiğı ve 24 gebe ise ev adreslerinde bulunamadığ araştırmaya dahil edilememiştir. Otuz dokuz gebe ise araştırmaya katılmaya gönüllü olmamıştır. Araştırma, 400 gebe ile tamamlanmıştır $(\mathrm{n}=400)$. Gebe kadınların yaşları 17-44 yaş arasında değişmekte olup yaş ortalaması

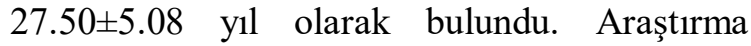
kapsamına alınan gebe kadınların \%35,2'sinin ilkokul ve altı ögrenim düzeyine sahiptir.

Çalışmada bilgi toplamak amacıyla, araştırmacılar tarafindan literatür bilgileri doğrultusunda hazırlanan "Gebelerde Obezite Değerlendirme Anket" formu ve "SF- 36 Yaşam Kalitesi Ölçeği" kullanıldı. Gebelerde Obezite Değerlendirme Anket formu 25 sorudan oluşmakta olup, kadınların bazı sosyodemografik özelliklerine, genel sağlik durumu ve alışkanlıklarına, jineko-obstetrik özelliklerine, beslenme alışkanlıklarına, boy ve kilo ölçümlerine ilişkin bilgilere yer verildi.

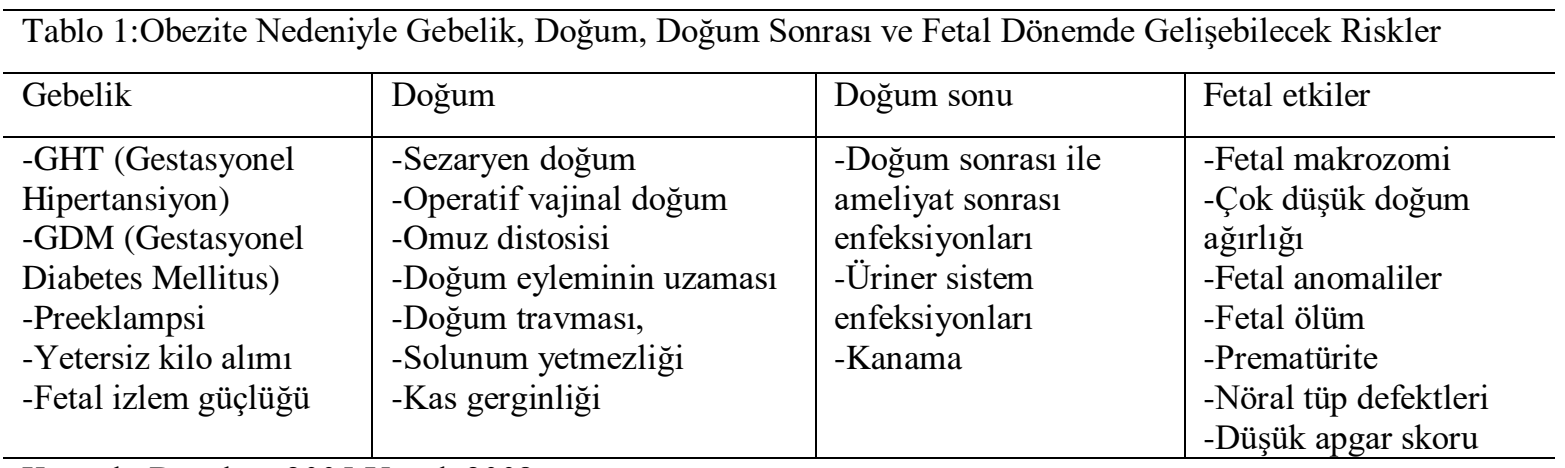

Kaynak: Duvekot, 2005; Yücel, 2008

\section{Gereç ve Yöntem}

$\mathrm{Bu}$ araştırma, gebelikte obezite prevalansını ve yaşam kalitesine etkisini değerlendirmek amacıyla yapılan, kesitsel tipte bir araştırmadır. Araştırma, 01 Haziran 2010 - 31 Mayıs 2011 tarihleri arasında Eskişehir Odunpazarı İlçesi, Büyükdere Aile Sağllğı Merkezi aile hekimlerine kayıtlı gebe kadınlar arasında gerçekleştirildi. Araştırma grubunu Aile Sağlığ Merkezi aile hekimlerine kayıtlı, araştırmaya
SF- 36 Yaşam Kalitesi Ölçeği, Ware tarafından 1987 yılında, klinik uygulama ve araştırmalarda, sağlık politikalarının değerlen-dirilmesinde ve genel popülasyon incelemelerinde kullanılmak üzere düzenlenmiş bireysel bir değerlendirme ölçeğidir. 1999 yılında Koçyiğit ve arkadaşları tarafından Türkiye'deki geçerlilik ve güvenirliliği yapılmıştır. ${ }^{13}$ Güvenilirlilik için ölçeğin iç tutarlılığ incelenmiş ve her bir alt 
ölçek için Cronbach alfa kat sayıları 0.73-0.76 arasında bulunmuştur. ${ }^{13}$

Anket formunun ön uygulamas1 10.05.2010-18.05.2010 tarihleri arasında Büyükdere Aile Sağlı̆̆ı Merkezine başvuran 20 gebe kadın ile gerçekleştirildi. Ön uygulama sonrası gerekli düzenlemeler yapılarak anket formuna son şekli verildi.

Elde edilen veriler bilgisayar ortamında SPSS (Version 15.0) istatistik paket programında değerlendirildi. Verilerin sayı ve yüzde dağılımları alındı. Analizler için; ki kare testi, student $\mathrm{t}$ testi kullanıldı. İstatistiksel anlamlılık için $\mathrm{p}<0.05$ değeri alındı.

Araştırmanın etik açıdan uygunluğunun değerlendirilmesi amaciyla Eskişehir Osmangazi Üniversitesi Tip Fakültesi Etik Kurul Başkanlığı'na başvuruldu ve 2010/144 sayılı etik kurul onayı alındı. Ayrıca Büyükdere Aile Sağlığı Merkezi'nde araştırma yapılabilmesi için Eskişehir Valiliği İl Sağlık Müdürlüğü'nden gerekli izin alındı.

\section{Bulgular}

Araştırmaya alınan 400 gebenin 75 'inde (\%18.8) obezite olduğu belirlenmiştir. Gebe kadınların $\% 11,3$ 'ü sigara içtiğini, $\% 6,5$ 'i daha önce sigara içip bıraktığını ifade etti. Çalışma grubunu oluşturan gebe kadınların obstetrik ve jinekolojik özelliklerine göre dağılımları Tablo 3'de görülmektedir. Buna göre, gebelerin \%6'sının infertilite tedavisi gördüğü belirlendi. Çalışma grubundaki gebe kadınların gebelik sayısı en az 1, en fazla 9 olup; ortalama gebelik sayıs1 $2.07 \pm 1.27$, canlı doğum sayısı ise en az 0 en çok 6 olarak bulunup, ortalama canlı doğum sayısı $0.69 \pm 0.80$ olarak saptandi. Kadınların \%17,8'inde düşük öyküsü, \%4,3'ünde ölü doğum öyküsü vardı. Daha önce doğum yapmış olan kadınların \%14,5'inde iri bebek öyküsü olduğu ve doğum yapan kadınların \%59,9'unun son doğum şeklinin vajinal doğum olduğu tespit edildi. Çalışmaya katılan kadınların günlük öğün sayıs1 1-3 arasında değişmekte olup ortalama ana öğün sayısı $2.84 \pm 0.41$ bulundu. Kadınların \%24'ünde öğün atlama alışkanlığı vardı. Öğün atlama alışkanlığ $\% 73,7$ 'si öğlen, \%2,1'i akşam ve \%13,7'si ise birden fazla öğünü atladığını belirtti. Kadınların $\% 30,7$ 'sinde hizlı yemek yeme, $\% 24,5$ 'inde gece yemek yeme, \%6,0'sinda yağlı yemek yeme ve $\% 24,5$ 'inde ayaküstü beslenme alışkanlığı olduğu tespit edildi. Gebe kadınların gebelik öncesi VKİ'ne göre dağılımlarına bakıldığında; kadınların gebelik öncesi \%6,5'inin zayıf, \%54,7'sinin normal kilolu, \%20,0'sinin fazla kilolu ve \%18,8'inin ise obez olduğu tespit edilmiştir.

Tablo 2'de obez olan ve olmayan gebelerin bazı sosyo-demografik özelliklere göre dağılımları yer almaktadır. Çalışmada, gebelerin yaş grupları ile obez olma durumu arasında istatistiksel anlamlı ilişki bulundu $(p<0.05)$. Otuz yaş ve üzeri gebelerde obezite oranı daha yüksek saptanmıştır. Gebelerin aile gelir durumları ile obez olma durumu arasinda istatistiksel anlamlı ilişki bulundu $(\mathrm{p}<0.05)$. Buna göre, gelir durumunu kötü olarak tanımlayan gebelerde obezite oranı daha yüksek saptandi. Çalışma grubundaki kadınlarda herhangi bir kronik hastalığı olanlarda obezite sıklı̆̆ 1 daha yüksek bulundu $(\mathrm{p}<0.001)$. Gebelerde ailede obezite öyküsü olanlarda obezite öyküsü olmayanlara göre obezite sıklığ 1 daha yüksek bulundu $(\mathrm{p}<0.001)$. Çalışmada düzenli fiziksel aktivitesi olmayan gebelerde fiziksel aktivitesi olanlara göre obezite s1klı̆̆ daha yüksek bulundu. Yapılan istatistiksel analizde fiziksel aktivite yapma durumu ile obezite arasında anlamlı ilişki bulundu $(\mathrm{p}<0.001)$. Günlük uyku süresi ve televizyon izleme süresi ile obezite olma durumu arasında istatistiksel fark bulunmuştur $(\mathrm{p}<0.05)$. Günlük altı saat ve daha az uyku süresi olan gebelerde ve beş saat ve daha fazla süre televizyon izleyenlerde obezite oranı daha yüksek saptand1 $(\mathrm{p}<0.001)$.

Tablo 3'de araştırma grubundaki obez olan ve olmayan kadınların obstetrik ve jinekolojik özelliklere göre dağılımlarına yer verilmiştir. Araştırma grubundaki kadınlar arasında daha önce infertilite tedavisi görenlerde infertilite tedavisi görmeyenlere göre obezite sıklığ 1 daha yüksek saptandı. Aralarındaki ilişki istatistiksel olarak anlamlıdır $(\mathrm{p}<0.001)$. Canlı doğum sayısı iki ve üzerinde olan gebelerde obezite s1klığı daha fazla bulundu $(\mathrm{p}<0.001)$. İri bebek öyküsü ve son doğum şekli sezaryen doğum olan gebelerin obezite olma durumları ile arasında istatistiksel anlamlı ilişki bulundu $(\mathrm{p}<0.05)$.

Tablo 4'te çalışma grubundaki obez olan ve olmayan gebelerin beslenme alışkanlıklarına göre dağılımları sunulmuştur. Çalışmamızda ögün atlama alışkanlığı, hızlı yemek yeme alışkanlığı, gece yemek yeme alışkanlığ ve ayaküstü beslenme alışkanlığ olan gebelerde obezite durumu ile yapılan istatistiksel analizde fark bulunmuştur $(\mathrm{p}<0.001)$. Ancak, yağl1 yemek yeme durumu ile obezite görülme 
Tablo 2. Obez Olan ve Olmayan Gebelerin Sosyo Demografik Özellikleri ve Genel Sağlık Durumu ve Alışkanlıklarına Göre Dağılımı

\begin{tabular}{|c|c|c|c|c|}
\hline \multirow[b]{2}{*}{ Özellikler } & \multicolumn{4}{|c|}{ Obezite } \\
\hline & $\begin{array}{l}\text { Var } \\
\mathrm{n}(\%)^{*}\end{array}$ & $\begin{array}{l}\text { Yok } \\
\text { n (\%)* }\end{array}$ & $\begin{array}{l}\text { Toplam } \\
\mathrm{n}(\%) * *\end{array}$ & $\begin{array}{l}\text { Test Değeri } \\
\left(\chi^{2} ; p\right)\end{array}$ \\
\hline \multicolumn{5}{|l|}{ Yaş grubu } \\
\hline$\leq 24$ & $12(9,2)$ & $118(90,8)$ & $130(32,4)$ & \multirow{3}{*}{$15.653 ;<0.001$} \\
\hline $25-29$ & $24(18,3)$ & $107(81,7)$ & $131(32,8)$ & \\
\hline$\geq 30$ & $39(28.1)$ & $100(71,9)$ & $139(34,8)$ & \\
\hline \multicolumn{5}{|l|}{ Aile gelir durumu } \\
\hline İyi & $24(18,0)$ & $109(82,0)$ & $133(33,3)$ & \multirow[b]{3}{*}{$19.661 ;<0.001$} \\
\hline Orta & $38(15,7)$ & $204(84,3)$ & $242(60,4)$ & \\
\hline Kötü & $13(52,0)$ & $12(48,0)$ & $25(6,3)$ & \\
\hline \multicolumn{5}{|l|}{ Kronik Hastalık } \\
\hline Var & $13(40,6)$ & $19(59,4)$ & $32(8,0)$ & \multirow[t]{2}{*}{$9.420 ; 0.002$} \\
\hline Yok & $62(16,8)$ & $306(83,2)$ & $368(92,0)$ & \\
\hline \multicolumn{5}{|c|}{ Ailede Obezite Öyküsü } \\
\hline Var & $46(58,2)$ & $33(41,8)$ & $79(19,8)$ & \multirow{2}{*}{$97.505 ;<0.001$} \\
\hline Yok & $29(9,0)$ & $292(91,0)$ & $321(80,2)$ & \\
\hline \multicolumn{5}{|c|}{ Düzenli Fiziksel Aktivite } \\
\hline Evet & $18(11,2)$ & $142(88,8)$ & $160(40,0)$ & \multirow[t]{2}{*}{$9.846 ; 0.002$} \\
\hline Hayır & $57(23,8)$ & $183(76,2)$ & $240(60,0)$ & \\
\hline \multicolumn{5}{|c|}{ Günlük Uyku Süresi (saat) } \\
\hline$\leq 6$ & $32(56,1)$ & $25(43,9)$ & $57(14,3)$ & \multirow{3}{*}{$75.092 ;<0.001$} \\
\hline $7-8$ & $38(19,4)$ & $158(80,6)$ & $196(49,0)$ & \\
\hline$\geq 9$ & $5(3,4)$ & $142(96,6)$ & $147(36,8)$ & \\
\hline \multicolumn{5}{|c|}{ Günlük Televizyon İzleme Süresi (saat) } \\
\hline$\leq 2$ & $26(16,0)$ & $137(84,0)$ & $163(40,8)$ & \multirow{3}{*}{$23.120 ;<0.001$} \\
\hline $3-4$ & $18(11,8)$ & $134(88,2)$ & $152(38,0)$ & \\
\hline$\geq 5$ & $31(36,5)$ & $54(63,5)$ & $85(21,3)$ & \\
\hline \multicolumn{5}{|l|}{ Evlilik Süresi (Yıl ) } \\
\hline $1-4$ y1l & $25(12,6)$ & $174(87,4)$ & $199(49,8)$ & \multirow{4}{*}{$13.556 ; 0.001$} \\
\hline 5- 9 yll & $26(20,8)$ & $99(79,2)$ & $125(31,2)$ & \\
\hline 10 yil ve $\uparrow$ & $24(31,6)$ & $52(68,4)$ & $76(19,0)$ & \\
\hline Toplam & $75(18,8)$ & $325(81,2)$ & $400(100,0)$ & \\
\hline
\end{tabular}

*:Satır toplamına göre, ${ }^{* *}:$ Sütun toplamına göre yüzde alınmıştır.

Tablo 3. Obez Olan ve Olmayan Gebelerin Obstetrik ve Jinekolojik Özelliklere Göre Dağılımı

\begin{tabular}{|c|c|c|c|c|}
\hline \multirow{3}{*}{$\begin{array}{l}\text { Bazı obstetrik ve jinekolojik } \\
\text { özellikler }\end{array}$} & \multicolumn{3}{|c|}{ Obezite } & \multirow{3}{*}{ Test Değeri $\left(\chi^{2} ; p\right)$} \\
\hline & Var & Yok & Toplam & \\
\hline & $\mathrm{n}(\%)^{*}$ & $\mathrm{n}(\%) *$ & $\mathrm{n}(\%)^{* *}$ & \\
\hline \multicolumn{5}{|l|}{ İnfertilite Tedavisi } \\
\hline Var & $11(45,8)$ & $13(54,2)$ & $24(6,0)$ & Fisher; 0.002 \\
\hline Yok & $64(17,0)$ & $312(83,0)$ & $376(94,0)$ & \\
\hline \multicolumn{5}{|l|}{ Canlı Doğum Sayısı } \\
\hline 0 & $27(15,0)$ & $153(85,0)$ & $180(45,0)$ & \multirow{3}{*}{$16.424 ;<0.001$} \\
\hline 1 & $32(17,5)$ & $151(82,5)$ & $183(45,7)$ & \\
\hline$\geq 2$ & $16(43,2)$ & $21(56,8)$ & $37(9,3)$ & \\
\hline \multicolumn{5}{|l|}{ İri Bebek Öyküsü $* * *$} \\
\hline Var & $24(72,7)$ & $9(27,3)$ & $33(14,5)$ & \multirow[t]{2}{*}{$56.182 ;<0.001$} \\
\hline Yok & $25(12,9)$ & $169(87,1)$ & $194(85,5)$ & \\
\hline Son Doğum Şekli *** & $15(11,0)$ & $121(89,0)$ & $136(59,9)$ & \multirow{4}{*}{$20.807 ;<0.001$} \\
\hline Vajinal Doğum & & & & \\
\hline Sezaryen Doğum & $34(37,4)$ & $57(62,6)$ & $91(40,1)$ & \\
\hline Toplam & $49(21,6)$ & $178(78,4)$ & $227(100,0)$ & \\
\hline
\end{tabular}

*:Satır toplamına göre, ${ }^{* *}$ :Sütun toplamına göre yüzde alınmıștır. 
durumu arasında istatistiksel olarak anlamlı fark bulunmamışırır ( $\mathrm{p}>0.05)$.

Tablo 5'te obez olan ve olmayan kadınların SF-36 Yaşam Kalitesi Ölçeği'nin alt alanlarından 'Fiziksel Fonksiyon, Fiziksel Rol, Ağrı, Genel Sağlık Algısı, Yaşamsallık, Sosyal İşlev, Mental Rol Ve Mental Sağlık' puan ortalamalarının dağılımına ait bulgulara yer verildi. Obez olan gebelerin SF-36'nın tüm alt boyutlarından aldıkları puan ortalamaları obez olmayan gebelere göre daha düşük bulundu. Ancak, Fiziksel Fonksiyon, Fiziksel Fiziksel Rol, Ağrı, Genel Sağlık Algısı, Yaşamsallık ve Sosyal İşlev alanları ile obezite durumu ile aralarında istatistiksel olarak anlamlı fark bulunmuştur $(p<0.05)$. Obez olan ve olmayan kadınların Mental Rol ve Mental Sağlık alanlarından aldıkları puanlar arasında istatistiksel fark saptanmadı ( $p>0.05)$.

Tablo 4. Obez Olan ve Olmayan Gebelerin Beslenme Alışkanlıklarına Göre Dağılımları

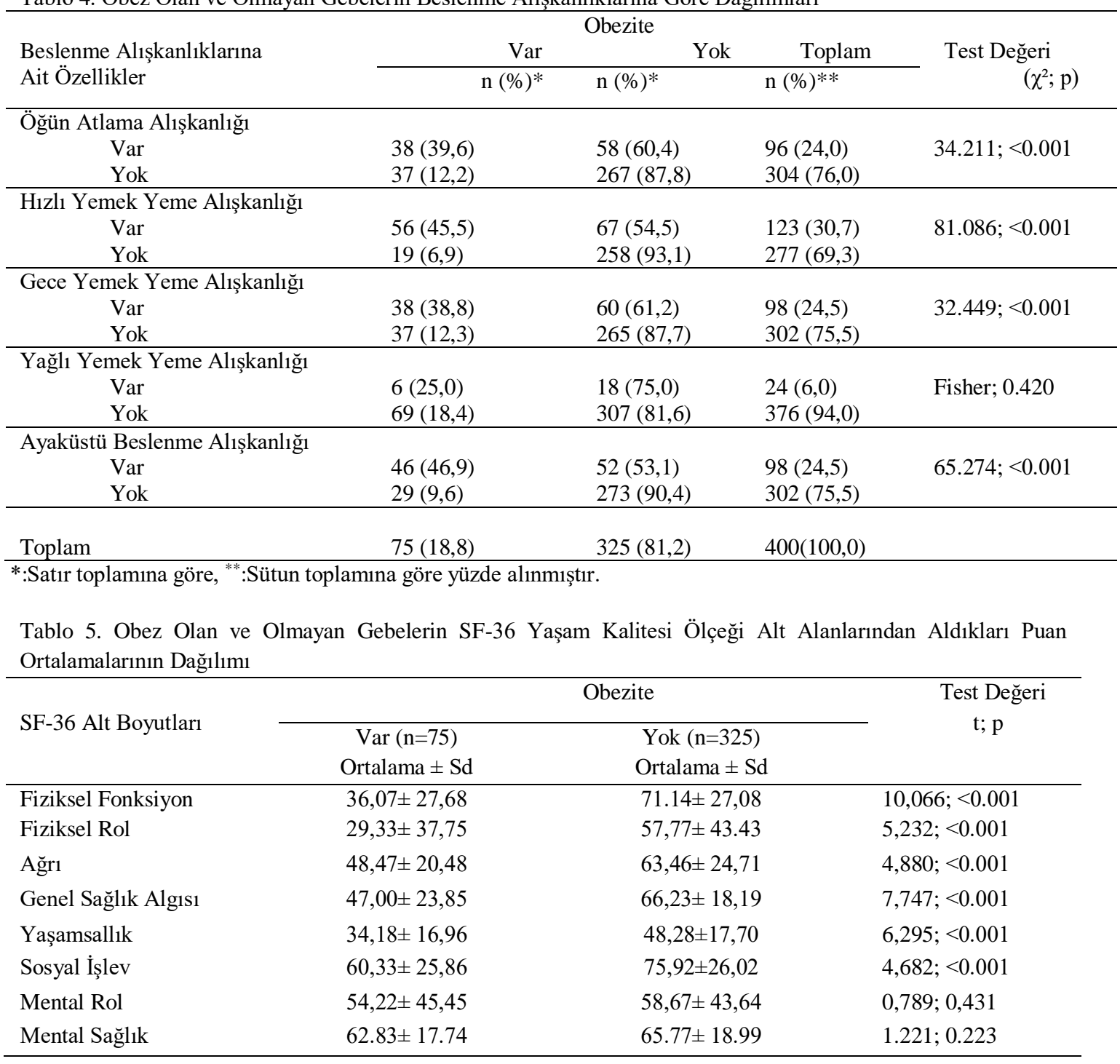

\section{Tartışma}

Çağımızın önemli bir sağlı sorunu olan obezitenin, tüm dünyada olduğu gibi toplumumuzda da sıklığı giderek artmaktadır. Gebelik öncesi obezite, maternal ve neonatal morbidite ve mortalite için bağımsız bir risk faktörüdür. ${ }^{15-17}$ Driul ve ark. yaptığı çalışmada gebelik öncesi obezite prevalans1 \%5.5, Ugwuja ve ark. yaptıkları çalışmada obezite sıklı̆̆ının $\% 17.2$ ve morbid obezite \%5.4, İngiltere'de 2006 yılında gebe kadınlarla yapılan bir çalışmada \%18.5, Susan ve ark. New York ve 26 eyalette yaptıkları çalışmada ise \%13.9 ile 
28.9 arasında değişen siklıklarda olduğu belirtilmektedir. Çalışmamızda gebe kadınlarda obezite sıklı̆̆ \%18,8 olarak bulunmakta olup, literatürde yer alan çalışma bulguları ile benzerlik göstermektedir. ${ }^{4,7,9,18,19}$

Obezite, farklı sistemleri etkileyen birtakım kronik hastalıklarla ilişkilidir. Kardiyovasküler hastalıklar, kanser, metabolik/endokrin hastal1klar, osteoartrit, lumbalji, respiratuar hastalıklar, bazı kanserler ve psikososyal hastalıkların nedeni olarak belirtilmektedir ${ }^{19}$. Yine bazı kronik hastalıkların ve bunların tedavisinde kullanılan ilaçların obezite nedeni olabileceği belirtilmektedir. ${ }^{19-21}$ Araştırma grubumuzu oluşturan kadınlar arasında kronik hastalığ 1 olanlarda obezite siklığı daha yüksek bulundu ( $\mathrm{p}<0.05)$. Yapılan bazı çalışmalarda da kronik hastalığ olan kadınlarda obezite sıklığının daha fazla olduğunu rapor edilmektedir. $^{20,22-24}$

Obezite doğurganlığ etkileyebilir. Kadınlarda obezitenin erken dönemde ortaya çıkması menstrüasyon düzensizliklerine, kronik oligo-anovülasyona ve erişkin yaşta infertiliteye yol açtığı bildirilmektedir. ${ }^{25}$ Aşırı yağ dokusunun nöroendokrin sistem üzerinde olumsuz etkisi olduğu, bunun da insülin rezistans1 (IR) ve hiperandrojenizmi arttırıp seks hormonunun işlevlerini bozduğu düşünülmektedir. Seks hormonu işlevlerindeki değişimler gebeliğin oluşumunu ve implantasyonu engelleyebilmektedir. ${ }^{26}$ Çalışmamızda infertilite tedavisi gören gebelerde obezite sıklı̆̆ 1 daha yüksek bulundu $(\mathrm{p}<0.05)$. Nohr ve ark. yaptıkları çalışmalarda da infertilite tedavisi gören gebe kadınlarda obezite sıklığının daha yüksek bulunduğu rapor edil-mektedir. ${ }^{27}$ Burstein ve ark. da fertilite tedavisinin maternal obezite ile ilişkili olduğunu bildirmektedir. ${ }^{28} \mathrm{Bu}$ araştırmadan farklı olarak Ventura ve Gatt'ın çalışmasında, yardımcı üreme teknikleri kullanımı ve gebelik öncesi obezite durumu arasında önemli bir ilişki bulunmadığı belirtilmektedir. $^{29}$

Doğum sayısı, yaşla birlikte obezite üzerinde etkilidir. Özellikle üçüncü doğumdan sonra gebeliğin vücut ağırlığına etkisi artmaktadır. Doğum sonras1 birinci yılda, gebelik öncesi döneme göre $1.5 \mathrm{~kg}$ bir artış görülmektedir. Gebelikte fazla kilo alınması doğumdan sonra bu kiloların daha kalıcı olmasına neden olmaktadır. Bu kilo artışında yaşam tarzındaki değişiklikleri, sürekli evde kalma ve sigaranın bırakılması gibi faktörlerin etkili olabileceği de düşünülmektedir. ${ }^{26}$ Çalış- mada canlı doğum sayısı iki ve daha fazla olan (multipar) kadınlarda obezite sıklığı daha yüksek bulundu $(\mathrm{p}<0.05)$. Yapılan diğer çalışmalar da çalışmamız ile benzerlik göstermekte olup, multipar kadınlarda fazla kiloluluk, obezite ve morbidobezite sıklığını daha yüksek bulduklarını belirtmektedir. ${ }^{18,29,30}$

Çalışmamızda son doğum şekli sezaryen doğum olan kadınlarda obezite sıklığı daha yüksek olarak saptand 1 ( $<0.05)$. Sheiner ve ark., Leung ve ark., Mclntyre ve ark., Hauger ve ark. da önceden sezaryen doğum yapmış olan gebe kadınlarda obezite sıklığını daha yüksek olduğunu belirlerken, çalışmamızdan farklı olarak Tosson ve Hussaini ise önceden sezaryen doğum yapmış olan gebe kadınlarda obezite s1klığını daha az buldukların belirtmektedir. ${ }^{31-33}$ Gebeliğin başlangıcındaki obezite ve gebelik boyunca komplikasyonlar gebeliğin ileri evrelerinde yaşam kalitesini olumsuz şekilde etkilemektedir. Obez gebelerde depresyon, beden imajinda bozulma, benlik saygisinda azalma ve sosyal izolasyon gibi psiko-sosyal problemler daha fazla görülür. Maternal obezitenin artan hipertansif bozukluklar, DM, infeksiyonlar gibi gebeliği olumsuz etkileyebilecek sonuçlara neden olması, gebe kadınların yaşam kalitesini olumsuz etkileyebileceği düşünülmektedir. Fakat gebelik öncesi kilo durumu ve sağlıkla ilgili yaşam kalitesi arasındaki ilişkiyi inceleyen çok az araştırma mevcuttur ${ }^{34}$. Çalışmamızda obez kadınların SF- 36 Yaşam Kalitesi Ölçeği'nin Fiziksel Fonksiyon, Fiziksel Rol, Ağrı, Genel Sağlık Algısı, Yaşamsallık ve Sosyal İşlev alanlarından aldıkları puanlar obez olmayan gebelere göre daha düşük bulundu. Kadınların Mental Rol ve Mental Sağlık alanlarından aldıkları puanlar arasında istatistiksel olarak anlamlı fark saptanmadı $(\mathrm{p}>0.05)$. Amador ve diğerlerine göre; gebeliğin başlangıcında ve üçüncü trimesterinde obez kadınların fiziksel ve mental komponent alanlarından aldıkları puanların obez olmayanlara göre daha düşük olduğu bildirilmektedir. ${ }^{34}$ Amador ve Guizar ise; gebeliğin ilk trimesterinde obez kadınların mental komponent alanından aldıkları puanların daha düşük olduğunu fakat fiziksel komponent alanından aldıkları puanlar arasında önemli bir fark olmadığını ifade etmektedir. ${ }^{35}$ Larsson ve diğerlerinin çalışmasına göre; obez kadınların obez olmayanlara göre SF- 36 ölçeğinin Fiziksel Fonksiyon, Ağrı, Genel Sağlık Algısı, Yaşamsallık ve Sosyal Fonksiyon alanlarından aldıkları puanların daha düşük olduğunu, fakat Fiziksel 
Rol, Mental Rol ve Mental Sağlık alanlarından aldıkları puanlar arasında bir ilişki bulunamadığ 1 belirtilmektedir. ${ }^{36}$ Tsai ve diğerleri ise; obez kadınların SF- 36 ölçeğinin Fiziksel Fonksiyon, Fiziksel Rol ve Ağrı alanından aldıkları puanların daha düşük olduğunu, fakat diğer alanlarda obezler ve obez olmayanlar arasinda puan ortalamaları açısından fark bulamadıklarını ifade etmektedir. ${ }^{37}$

\section{Sonuçlar}

Doğurganlık çağındaki kadınlarda obezite önemli bir sağllk problemidir. Gebeliğe obez olarak giren kadınların yaşam kalitesinin fiziksel alanının mental alandan daha fazla etkilendiği bulunmuştur. Obezite, gebelerin yaşam kalitesini etkilemektedir. Araştırmada, SF-36 Yaşam kalitesi Ölçeğinin alt boyutları ile obez olma durumu arasında istatistiksel fark olduğu belirlenmiştir. Çalışmada yaş arttıkça obezite sıklığının da arttığı saptanmıştır.

Gebelik planlayan obez kadınlar için, kilo verilmesi ya da kilonun kontrol altına alınması için prekonsepsiyonel bakım alınmasının sağlanması, kilo vermeye yönelik beslenme ve egzersiz programlarının gebelik öncesi dönemde planlanması, gebelik süresince komplikasyonları erken tanılamak ve önlemek için hem gebenin hem de fetüsün her prenatal bakımda değerlendirilmesi, gebelik süresince gebenin kilo ve diyetinin takip edilmesi, gebe ve ailesi ile etkili iletişimin sağlanması, gebelik öncesinde ve doğum öncesinde gebeye oluşabilecek komplikasyonlar hakkında bilgi verilmesi, obezite ve gebelik ile ilgili araştırmaların daha fazla örneklem grubuyla yapılması önerilmektedir.

\section{Kaynaklar}

1. World Health Organization. Global Strategy on Diet Physical Activity and Health, 2008.

2. Gümüşler A. Rize Çayeli İlçesindeki Lise Öğrencilerinde Obezite Sıklığı ve Beslenme Alışkanlıkları [Yüksek Lisans Tezi]. Karadeniz Teknik Üniversitesi Sağllk Bilimleri Enstitüsü, Trabzon, Türkiye, 2006.

3. Katzmarzyk PT. The Canadian Obesity Epidemic: An Historical Perspective. Obesity Research, 2002;10(7):666-674.

4. Khashan AS, Kenny LC. The Effects of Maternal Body Mass Index on Pregnansy Outcome. Eur J Epidemiol, 2009;24:697705 .
5. Duvekot JJ. Prepregnansy and Obesity: Pratical Implications. Eur Clinics Obstet Gynaecol, 2005;1:74- 88.

6. Yücel N. Kilolu ve Obez Kadınlarda Obezite ve Benlik Saygısı İlişkisinin Değerlendirilmesi [Yüksek Lisans Tezi]. Marmara Üniversitesi Sağlık Bilimleri Enstitüsü, İstanbul, Türkiye, 2008.

7. Driul L, Cacciaguerra G, Citossi A, DellaMartina M, Peresini L, Marchesoni D. Prepregnansy Body Mass Index and Adverse Pregnansy Outcomes. Arch Gynecol Obstet, 2008;278:23- 26.

8. Smith SA, Hulsey T, Goodnight W. Efffects of Obesity on Pregnansy. JOGNN, 2008;37:176-184.

9. Chu SY, Kim SY, Bish CL. Prepregnansy Obesity Prevalence in The United States 2004-2005. Matern Child Health J, 2009;13:614-620.

10. Apay SE, Kılıç M, Pasinlioğlu T. Obez Gebelerde Doğum Eylemi ve Doğum Sonu Dönem. TAF Preventive Medicine Bulletin, 2010;9(2):151- 156.

11. Aydin C, Baloğlu A, Yavuzcan A, İnci A. The Effect of Body Mass Index Value During Labor on Pregnansy Outcomes in Turkish Population (Obesity and Pregnansy Outcomes). Arch Gynecol Obstet, 2010;281:49-54.

12. Acaray A, Pınar R. Kronik Hemodiyaliz Hastalarının Yaşam Kalitesinin Değerlendirilmesi. C.Ü. Hemşirelik Yüksek Okulu Dergisi, 2004;8(1):1-11.

13. Koçyiğit H, Aydemir Ö, Ölmez N, Memiş A. Reliabilitiy and Validity of The Turkish Version of Short- Form (SF- 36). Turkish J Drugs Therapy, 1999;12:102-106.

14. Guelinckx I, Devlieger R, Beckers K, Vansant G. Maternalobesity: Pregnancy Complications, Gestational Weight Gain and Nutrition. Wiley Online Library, 2008;9(2):140-150.

15. Dündar Ö, Çiftpınar T, Tütüncü L, Ergür AR, Atay MV, Müngen E. Gebelik Öncesi Maternal Vücut Kitle İndeksinin Perinatal Sonuçlara Etkisi. Perinatoloji Dergisi, 2008;16(2):43- 48.

16. Mannucci E, Petroni ML, Villanova N, Rotella CM, Apolone G, McIntyre HD et al. Overweight and Obesity in Australian Mothers: Epidemic or Endemic? MJA, 2012;196:184-188.

17. Krishnamoorthy U, Schram CM, Hill SR. Maternal Obesity in Pregnancy: Is it Time 
For Meaning Ful Research To Inform Preventive and Management Strategies?. BJOG, 2006;113(10):1134-1140.

18. Ugwuja E I, Akubugwo EI, Obidoa O, Ibiam AU. Maternal BMI During Pregnancy: Effect on Trace Elements Status and Pregnancy Outcomes. International Journal of Health Research, 2010;3(2):71-78.

19. Gülcan E, Özkan A. Obezite. D.P.Ü. Fen Bilimleri Enstitüsü Dergisi, 2006;10:185194.

20. Koruk İ, Şahin TK. Konya Fazilet Uluışık Sağl1k Ocağ1 Bölgesinde 15-49 Yaş Grubu Ev Kadınlarında Obezite Prevalansı ve Risk Faktörleri. Genel Tip Dergisi, 2005;15(4):147-155.

21. Işık NB. Diyarbakır Silvan İlçesi Devlet Hastanesi İç Hastalıkları Polikliniğine Herhangi Bir Sebeple Başvuran Hastalarda Obezite-Beslenme Durumu ve Kan Lipid Profili Arasındaki İlişkinin Araştırılması [Yüksek Lisans Tezi]. Haliç Üniversitesi Sağlık Bilimleri Enstitüsü, İstanbul, Türkiye, 2010.

22. Okyay $P$, Uçku R. İzmir'de Kentsel Bir Bölgedeki Doğurgan Çağdaki Kadınlarda Şişmanlık Prevalansı ve Risk Faktörleri. ADÜ Tıp Fakültesi Dergisi, 2002;3(3):5- 12.

23. Raatikainen K, Heiskanen N, Heinonen S. Transition from Overweight to Obesity Worsens Pregnancy Outcome in a BMIdependent Manner. Obesity, 2006;14(1):165171.

24. Nazlıcan E. Adana İli Solaklı ve Karataş Merkez Sağlık Ocağı Bölgesinde Yaşayan 20- 64 Yaş Arası Kadınlarda Obezite ve İlişkili Risk Faktörlerinin İncelenmesi [Uzmanlık Tezi]. Üniversitesi Tıp Fakültesi Halk Sağlığı Anabilim Dalı, Adana, Türkiye, 2008.

25. Pasquali R, Patton L, Gambineri A. Obezite ve İnfertilite, Current Opinion in Endocrinology. Diabetes \& Obesity, 2008;3(1):10- 16.

26. Apay SA, Pasinlioğlu T. Obezite ve Gebelik. TAF Preventive Medicine Bulletin, 2009;8(4):345- 350.

27. Nohr EA, Bech BH, Davies MJ, Frydenberg M, Henriksen B, Olsen J. Prepregnancy Obesity and Fetal Death. Obstetrics \& Gynecology, 2005;106(2):250-259.

28. Burstein E, Levy A, Mazor M, Witnitzer A, Sheiner E. Pregnancy Outcome Among Obese Women: A ProspectiveStudy. Amer J Perinatol, 2008;25(9):561-566.
29. Ventura CS, Gatt M. Short-Term Obstetric Outcomes in Obese Maltese Women. Int $\mathbf{J}$ Diabetes \& Metabolism, 2006;4:88-91.

30. Kungobol A, Phupong V. Pregnancy Obesity and The Risk of Gestational Diabetes Mellitus. BMC Pregnancy and Childbirth, 2011;11(59):1471-2393.

31. Sheiner E, Levy A, Menes TS, Silverberg D, Katz M, Mazor M. Maternal obesity as an Independent Risk Factor for Caesarean Delivery. Paediatric and Perinatal Epidemiology, 2004;18:196-201.

32. Leung TY, Leung TN, Sahota DS, Chan OK, Chan LW, Fung TY et al. Trends in Maternal Obesity and Associated Risks of Adverse Pregnancy Outcomes in a Population of Chinese Women. BJOG An International Journal of Obstetrics and Gynaecology, 2008;115:1529-1537.

33. Tosson MM, Al-Hussaini TK. The Impact of Maternal Obesity on Pregnancy Outcome at Assiut University Hospital. Ass. Univ. Bull. Environ. Res, 2005;8(2):1-11.

34. Amador N, Juarez JM., Guizar JM, Linares B. Quality Of Life in Obese Pregnant Women: A Longitudinal Study. American Journal of Obstetrics \& Gynecology, 2008;203-204.

35. Amador-Licona N, Guizar-Mendoza JM. Day Time Sleepiness and Quality of Life: Are They Associated in Obese Pregnant Women? Arch Gynecol Obstet, 2012;285:105-109.

36.Larsson U, Karlsson J, Sullivan M. Impact of Over Weight and Obesity on Health-related Quality of Life-a Swedish Population Study. International Journal of Obesity, 2002;26(3):417.

37. Tsai WL, Yang CY, Lin SF, Fang FM. Impact of Obesity on Medical Problems and Quality of Life in Taiwan. American Journal of Epidemiology, 2004;160(6):557-565.

38. Türkiye Nüfus ve Sağlık Araştırması 2013. Hacettepe Üniversitesi Nüfus Etütleri Enstitüsü, Ankara, Kasım 2014. 